\title{
Narrar/Editar: faces do realismo refratado em De mim já nem se lembra (2007), de Luiz Ruffato
}

\author{
Paulo Alberto da Silva Sales \\ Instituto Federal Goiano, Campus Avançado Hidrolândia / \\ Universidade Estadual de Goiás, Campus Cora Coralina, Brasil \\ https://orcid.org/0000-0001-9980-2561
}

\begin{abstract}
RESUMO
Este artigo propõe a leitura do romance De mim já nem se lembra (2007), de Luiz Ruffato, a partir da perspectiva do realismo refratado, por meio da qual há a possibilidade de criação e atribuição de valor aos modos de vida de sujeitos esquecidos pela história. Ao entrecruzar instâncias narrativas distintas, tanto pela narração autodiegética quanto pela editoração de supostas cartas de autoria de José Célio, irmão do narrador, Ruffato revitaliza formas distintas de representar e de problematizar o real. Nessas articulações entre diferentes estratégias de apropriação realistas, destacam-se as epístolas, cuja escrita registra a vida cotidiana de um sujeito comum, que presencia e vivencia experiências da ditadura civil-militar. Por fim, com base nos estudos da nova história, constatam-se outras dimensões dos anos de chumbo por meio de "pormenores concretos" nas epístolas, bem como a narração, que impossibilitados de representar o real per se, configuram-se refratários.
\end{abstract}

PALAVRAS-CHAVE: Luiz Ruffato; Narrar/Editar; Realismo refratado; Escrita epistolar; Ditadura.

\section{To Narrate/To Edit: faces of refracted realism in De mim já nem se lembra (2007), by Luiz Ruffato}

\section{ABSTRACT}

This article proposes a reading of the novel De mim já nem se lembra (2016), by Luiz Ruffato from refracted realism perspective through which it is possible the creation and assignment of value to the subjects' lifestyles that were forgotten by history. By intertwining different narrative instances either of autodiegetic narration or the letters supposedly written by José Célio, the narrator's brother, Ruffato revitalizes distinct forms of representing and problematizing the real. In the articulations between different realistic strategies the letters stand out as records of the everyday life of a common guy who witnesses and experiences during the militarycivilian dictatorship. Lastly based on new history studies other dimensions of dictatorship years are revealed by reading letters concrete details as well as the narration that, unable to represent the real itself, becomes refractory.

KEYWORDS: Luiz Ruffato; To narrate/To edit; Refracted realism; Epistolary writing; Dictatorship. 


\begin{abstract}
Nossas mentes não refletem diretamente a realidade. Só percebemos o mundo através de uma estrutura de convenções, esquemas e estereótipos, um entrelaçamento que varia de uma cultura para a outra. Nessa situação, nossa percepção dos conflitos é certamente mais realçada por uma apresentação de pontos de vista do que por uma tentativa de articular um consenso. Nós nos deslocamos do ideal de Voz da História para aquele da heteroglossia, definida como "vozes variadas e opostas". (BURKE, 2011, p. 15-16)
\end{abstract}

Sendo o realismo [...] um tipo de narrativa que cria e atribui valor às especificidades e detalhes de um modo de vida, em termos das características particulares dos indivíduos, dando o mesmo valor ao conjunto da sociedade de que fazem parte, ele compõe uma visão do todo, organizado com as diversas modalidades de experiência representadas e, devido a essa complexidade e historicidade, não é homogêneo. (PELLEGRINI, 2018, p. 243-244)

\title{
1. 0 Realismo na contemporaneidade
}

Se fôssemos tentar definir quais seriam as principais linhas de força da ficção brasileira contemporânea, principalmente naquelas obras situadas nas últimas três décadas do século XX e nos dois primeiros decênios do XXI, certamente a "persistência" da representação realista seria uma delas. Temos nos deparado com narrativas mimeticamente comprometidas com a representação de elementos do real por meio de diversas estratégias de escrita. Contudo, as várias modificações nas formas de representar o real pelas quais passaram as escritas realistas, desde a ficção machadiana aos experimentalismos modernistas de Oswald de Andrade, Mário de Andrade e, também, os romances de 1930, não se percebe, na contemporaneidade, uma tendência na ficção à descrição ou à reprodução de realidades em sua totalidade, mas caminhos em torno da "refração" realista na qual "o seu conteúdo original [real] é modificado, o que envolve, inclusive, questões ideológicas e políticas" (PELLEGRINI, 2009, p. 22).

Em Realismo e realidade na literatura: um modo de ver o Brasil, Tânia Pellegrini examina as diversas formas da ficção realista brasileira - do século XIX ao século XXI - ao perscrutar o realismo como um fenômeno que possibilita a compreensão estética da vida social. Por essa via de análise, a autora apresenta a noção de "realismo refratado" que, diferentemente do sentido descritivo inicial característico dessa estética, tem se manifestado em narrativas brasileiras contemporâneas através de formas particulares que evidenciam a relação entre os indivíduos e a sociedade. Valendo-se da refração realista, “[...] é possível ultrapassar a noção de um simples processo de registro, dependendo, para sua plena elaboração, da descoberta de novas formas de percepção e, em consequência, de representação artística" (2018, p. 17). Segundo a crítica, as multifacetadas formas narrativas contemporâneas, apesar de trazerem a fragmentação, a estili- 
zação, a colagem, a montagem, as elisões e as abstrações de forte traço modernista que poderiam apontar, hoje, a "crise" da crise da representação, essas ficções convivem, agora, com outros modos de representação. A perspectiva de realismo refratado procura esmaecer a ideia de totalidade por meio de uma convenção literária composta por muitas faces: eis, segundo a estudiosa, o porquê de entendê-la como refração, ou, também, como uma decomposição de formas e cores.

Tais configurações refratárias traduzem situações específicas de muitas sociedades contemporâneas. No caso específico da ficção brasileira recente, destaca-se, como também aponta Pellegrini, cenas de escrita sobre a caótica vida urbana, sobre a desigualdade social e sobre a violência crescente que, também, aparecem interrelacionadas à sofisticação tecnológica das comunicações e da indústria cultural. Logo, nota-se, por meio da leitura de textos ficcionais dos últimos decênios, que a perspectiva de representação refratária da realidade se detém na proposta realista em criar, ao mesmo tempo, a representação do sujeito e do objeto e não entre alguma coisa e o sujeito que está relacionado.

Muito embora a estética realista tenha se firmado, primeiramente, por meio de acontecimentos históricos em solo francês, mais precisamente entre os anos 1830 e 1840, suas primeiras manifestações literárias estão intimamente ligadas às questões filosóficas do real e da realidade. No trânsito de fronteiras entre França e Inglaterra, cujo princípio do "realismo formal" - tão caro a Ian Watt (1990) - norteou os projetos literários de Daniel Defoe, em Moll Flanders (1722), de Samuel Richardson, em Clarissa (1747) e de Henry Fielding, em Tom Jones (1749), começou-se a perceber como os romances realistas se apropriavam das histórias de sujeitos, sobretudo relacionadas aos indivíduos pertencentes às classes populares. Nessa esteira, seguiram os grandes escritores realistas do século XIX - Balzac, Zola, Eça de Queirós, dentre outros - que criaram, por intermédio da retratação de universos particulares de sujeitos da pequena e da grande burguesia, a ilusão referencial inerente ao próprio gênero romanesco, desde sua ascensão. Aliás, o romance, na acepção bakhtiniana, é o gênero que melhor se apropria dos elementos da realidade burguesa, muito embora sempre tenha sido um gênero indefinido. Ora,

[...] falando estritamente, com efeito, tudo é "fingido" num mundo criado em todas as peças para ser escrito: sejam quais forem o tratamento que receba e a forma sugerida, a realidade romanesca é fictícia, ou mais exatamente, é sempre uma realidade do romance, em que personagens de romance têm nascimento, morte e aventuras de romance. [...] O grau de realidade de um romance nunca é coisa mensurável, representando apenas a parcela de ilusão que o romancista deseja representar (ROBERT, 2007, p. 18).

$\mathrm{Na}$ tessitura romanesca, tal como assevera Robert, cria-se o heterocosmo fictício por meio do qual se constrói o grau de realidade que o romancista almeja representar. A reiterada inserção de elementos do real na ficção, por outro lado, levou à crise da representação da narrativa realista, fazendo com que o gênero passasse por várias mudanças e adaptações. Primeiramente, ligado à perspectiva de representar objetivamente a realidade social, sem espaço para os escapismos românticos, o romance primava pelo aspecto descritivo de elementos para além das estruturas narrativas - os "pormenores concretos" -, criando, assim, o "efeito do real" (BARTHES, 2004, p. 181). Com as mudanças sociais, as formas e os conteúdos dos romances realistas tam- 
bém se adequaram às vidas e aos contextos dos sujeitos. Na contemporaneidade, mais precisamente nas produções das décadas de 1970 até os dois decênios do século XXI, é notório como os romancistas ainda têm incorporado - tomada as devidas proporções, quando comparados com as primeiras narrativas realistas - aspectos do real em suas produções por meio de experimentalismos de discursos e pelo hibridismo de gêneros. Segundo Schollhammer, o retorno desse "novo realismo" se expressa em diferentes maneiras de relacionar a literatura e a arte com a realidade social e cultural da qual emerge (2009, p. 54). Nessas criações, a ilusão referencial incorpora no bojo das obras as realidades desses sujeitos em seus contextos originais. Em outras palavras, são realismos que conjugam ambições de serem referenciais sem, necessariamente, serem representativos.

Nesse sentido, tanto a epígrafe de Peter Burke (2011), importante nome dos estudos sobre as novas escritas da história, quanto a de Pellegrini (2018) - cujos estudos sobre a estética realista se debruçam sobre as reiteradas tentativas de apreensão da realidade por meio da narrativa ficcional - convergem para um determinante comum que norteará a reflexão que ora propomos: a constatação de que, por meio da observação e da análise de pontos de vista de sujeitos da/na história e dentro do romance, bem como do resgate das memórias subalternas ou "clandestinas" (POLLAK, 1989, p. 3-15) desses indivíduos, é possível constituir representações que consigam reproduzir a "suficiência" (PELLEGRINI, 2018, p. 241) do real. Essa capacidade apropriativa das novas ficções realistas são mediadas, claro, por meio de leituras que destacam os discursos de sujeitos-protagonistas de suas histórias.

Embora Burke e Pellegrini se ocupem de conhecimentos distintos, nota-se, em seus discursos, uma tentativa de validar a "história vista de baixo" (SHARPE, 2011, p. 39). Ambos levam em consideração as opiniões das pessoas comuns e suas experiências na vida em sociedade para a reconstituição do que os novos historiadores chamam de "história total" - sobretudo relacionada aos historiadores dos Annales - segundo os quais "tudo tem uma história". Logo, dialogando com a perspectiva da história vista de baixo, o realismo refratado torna-se, a nosso ver, uma estratégia fecunda de representação realista, se pensarmos nas diferentes geografias e manifestações da literatura das últimas décadas, quando encaradas como "uma forma particular de captar a relação entre os indivíduos e a sociedade" (PELLEGRINI, 2018, p. 17). Se adotarmos essa perspectiva, podemos pensar historicamente o conceito, o que nos leva a acompanhar as transformações do real. Esse interesse pela história social, sobretudo na tentativa de recuperar a história das classes subalternas a partir de seu próprio ponto de vista, também está presente na conhecida linha dos estudos historiográficos da escola social inglesa, com a publicação, em 1966, de "The History from below", no The Times Literary Supplement, bem como também se liga à perspectiva de investigação de memórias dos sujeitos por meio do "lembrar, escrever, esquecer" (GAGNEBIN, 2006).

No entrelaçamento de enfoques dialógicos entre história e ficção, aliando-nos à ideia de que "o real precisa ser ficcionado para ser pensado" (RANCIÈRE, 2009, p. 58), valemo-nos da perspectiva da história vista de baixo e, por meio dela, podemos ler fissuras do real que são ficcionalizadas no romance De mim já nem se lembra, de Luiz Ruffato. Ou seja, pela representação refratária, percebemos como o escritor mineiro se vale da mescla de diferentes formas de 
revistar o passado. Ruffato o faz por meio de uma escrita que entremeia memórias individuais às memórias coletivas através de "lugares da memória" que, segundo Pierre Nora (1985), se manifestam através do patrimônio arquitetônico e seu estilo que nos acompanham por toda a vida, tais como as paisagens, as datas e os sujeitos atores de suas histórias.

\section{0 Realismo refratário em De mim já nem se lembra}

Publicado inicialmente pela editora moderna em 2007, De mim já nem se lembra foi, à época, destinado ao público infanto-juvenil. Em 2016, após alguns reajustes e acréscimos, a editora Companhia das Letras o publicou em definitivo, tanto para o público infanto-juvenil quanto adulto. Nessa trama, constrói-se um hibridismo discursivo que mescla memórias pessoais a fatos e contextos de repressão. A iniciar pelo título, percebe-se que o romancista revitaliza elementos do passado por meio da intertextualidade: "De mim já nem se lembra" é o nome de uma composição do século XVIII bastante conhecida em Vila Rica, hoje Ouro Preto, em Minas Gerais. Para além dessa retomada, a escrita romanesca se propõe a vasculhar memórias de um passado traumático, marcado por perdas de familiares do autor, agora, ficcionalizados. A ideia de um elemento do passado que se interliga a outro é sugerida pela própria capa do romance. Ela apresenta uma fotografia em cor preta e branca, na qual se percebe uma avenida movimentada - supostamente de um cruzamento do município de Diadema, SP - que integra a região do Grande $\mathrm{ABC}$, cidade muito citada no enredo. Essa mesma fotografia é rasgada ao meio e, nela, se torna visível um papel de tonalidade parda, típica de papéis antigos que, também, aludem à escrita manual e epistolar. A coloração parda do papel presente na capa do livro também faz menção à materialidade do próprio objeto livro, no que diz respeito à sua configuração, o que incide fortemente no trabalho composicional de Ruffato.

Por meio da leitura dos diversos elementos presentes na narrativa, nota-se uma composição que articula fissuras do real por meio de hibridismos de escrita, que tanto se vale de uma vertente engajada quanto experimental. As estratégias de construção do realismo refratado no enredo de Ruffato se realizam de diversas formas que, dentre outras questões, levam os leitores a se indagarem se

\footnotetext{
[...] toda ficção acaba estabelecendo uma espécie de teorização sobre o real, na medida em que é o resultado de um olhar ao mesmo tempo criativo e interpretativo sobre as coisas. Assim, faz-se retrato e testemunho, por um lado, mas também, criação, por outro, pois as imagens que propõe são recomposições, rearticulações do que se retrata e testemunha. Essa teorização do real tem a sua especificidade, dada pela natureza do próprio objeto, a realidade, em todas as dimensões, concebida em sua totalidade, mas da qual se elegem um ou mais detalhes para representar, utilizando convenções artísticas e convenções estéticas próprias de cada época (PELLEGRINI, 2018, p. 241).
}

A representação do real nesse romance promove tanto a teorização sobre o real quanto o problematiza. Sua recepção faz com que o leitor, do início ao término do texto, desconstrua a ideia de realismo objetivo e descritivo. Trata-se de uma diegese que se serve de diferentes 
instâncias narrativas que criam ilusões referenciais: há, na trama, o intercâmbio entre registros memorialísticos e supostos elementos biográficos do autor que estão, por sua vez, relacionados aos tempos do regime opressor.

$\mathrm{Na}$ fortuna crítica consultada sobre o romance - tanto estudos mais rápidos realizados por meio de resenhas quanto os de maior fôlego em forma de artigos ou mesmo dissertações - percebe-se a exegese de aspectos relacionados ao passado, tais como o luto e o trauma, bem como também há pesquisas que se atêm à configuração do sujeito migrante na ficção de Ruffato ${ }^{1}$. Contudo, ainda faltam estudos que se debrucem sobre o problema da representação realista em si, sobretudo, no que diz respeito a novas configurações refratárias a partir do hibridismo entre história e ficção.

A reflexão de Gecielli Fritzen, por exemplo, se detém na leitura dos modos de vida e no trabalho fabril no romance, partindo do contexto da primeira revolução industrial até o contexto histórico das décadas de 1970. Nesse estudo, a autora reflete sobre o movimento de migração de trabalhadores do interior do país para os centros urbanos e seus infortúnios:

Sabemos que a década de 70 foi significativamente marcada pelo processo de migração de trabalhadores do meio rural para o meio metropolitano. E, se no campo estes trabalhadores exerciam atividades relacionadas com o cultivo da terra, na nova conjuntura social em que se encontram estes indivíduos, primeiro, irão se deparar com o desemprego provisório, para posteriormente buscarem ocupar as vagas de trabalho que melhor condizem com seus perfis educacionais e de experiência anteriores. Foi neste contexto e nesta época que muitos sujeitos começaram a realizar atividades como as de construtores civis, motoristas de ônibus, vendedores ambulantes, empregadas domésticas e trabalhadores fabris. Este último em menor escala que as demais funções por exigir, na maioria dos casos, um nível maior de qualificação (FRITZEN, 2015, p. 62).

É justamente nesse contexto dos anos 1970 que Ruffato configura o seu romance, cuja fatura, em boa parte do enredo, se apropria de elementos do real por meio da revitalização da prática da escrita epistolar. Trata-se dos "anos de chumbo", década em que houve o apogeu e o declínio da ditadura civil-militar ${ }^{2}$ brasileira e na qual se propagou o "milagre econômico" do "Brasil grande", sob a égide do poder executivo. Ideais como "Brasil, ame-o ou deixe-o" eram propagados por diversos meios nesses governos totalitários. Nessa época, principalmente a partir dos anos 1968, a sociedade brasileira vivenciou o período mais sombrio desde 1964, quando o grupo castelista ${ }^{3}$ implantou o golpe militar. Na sucessão dos governos de Garrastazu Médici (1968-1974) e de Ernesto Geisel (1974-1979), principalmente, houve inúmeros sujeitos que foram presos, torturados, mortos ou que nunca foram encontrados. Governava-se, então, por meio de decretos-leis

\footnotetext{
${ }^{1}$ A esse respeito, ver 0 estudo "Abandono e sobrevivência: o sujeito migrante na obra de Luiz Ruffato" (2012), de Silvina Carrizo e Rodrigo Cerqueira, no qual os autores também leem o romance De mim já nem se lembra.

2 Há um consenso entre os historiadores quanto à designação da ditadura dessa época como civil-militar, visto que uma parcela significativa da sociedade civil compactuou com os princípios repressores dos militares. Aqui, reportamo-nos às reflexões presentes em 1964: História do regime militar brasileiro (NAPOLITANO, 2019).

3 Grupo dos generais ligados ao Presidente Castelo Branco, que também eram conhecidos como "grupo da Sorbonne" (alusão à universidade francesa).
} 
apoiados quase exclusivamente no CNS (Conselho de Segurança Nacional), protegido pelo AI-5 (Lei de Segurança Nacional, da censura e do pesado aparato repressivo). Naqueles anos,

[...] nem o Presidente e nem os ministros prestavam contas de suas determinações seja ao Legislativo ou a quem quer que fosse. O general Médici, em todo seu governo, deu uma única entrevista coletiva à imprensa e, mesmo assim, lendo respostas a perguntas que lhe foram previamente entregues. Nenhuma autoridade respondia às denúncias de prisões, torturas e assassinatos de presos políticos e comuns. A aplicação das decisões ficava a cargo de uma tecno-burocracia civil e militar que se tornou um setor decisivo na administração dos assuntos econômicos e políticos e no estreitamento das relações entre o governo e a burguesia (HABERT, 2006, p. 25-26).

Embora o romance não faça, explicitamente, menções a governos militares específicos, verificam-se descrições de acontecimentos "estranhos" acometidos a sujeitos nas cartas que integram a segunda parte do romance, datadas de 1971 a 1978. Antes dessas alusões aos fatos históricos por meio da editoração de missivas, a voz narrativa, em registros memorialísticos, revela-se pertencente à classe menos favorecida. Logo, esse narrador, ao apropriar-se do ponto de vista das minorias e dos sujeitos silenciados pelos discursos históricos "oficiais", configura, através da criação de memórias de subalternos, uma outra visão sobre a ditadura.

Partindo dessa ambientação, nossa leitura se detém nas instâncias narrativas que evidenciam, como indica Pellegrini, a relação entre sujeito e objeto representados: a presença concomitante tanto do narrador autodiegético ${ }^{4}$, sobretudo com uma focalização interna fixa, quanto a de um editor de cartas, cuja autoria é atribuída ao personagem central do romance: José Célio, o irmão do narrador, vitimado por um suposto acidente automobilístico, em 1978.

A configuração que o narrador faz de seus familiares, da paisagem, dos registros de variantes linguísticas não padrão, utilizados pelas personagens, bem como a descrição dos sujeitos que viviam em Cataguases, interior de Minas Gerais, revela uma vida modesta. Nas primeiras páginas da narrativa, a voz autodigética conduz o leitor à ambientação que reproduz elementos de uma realidade humilde, cujos protagonistas aparentam possuir poucos recursos financeiros. Esses aspectos são narrados por meio da concatenação da memória do narrador às falas de seus entes. Ao rememorar aspectos de seus pais, a instância, assim, os caracteriza:

Viviam. Ela trazia sempre arrumada uma "bolsa de viagem" - camisola, muda de roupa, chinelo, sandália, escova de cabelo e de dentes, documentos - "para alguma precisão", que se manifestava no soar do telefone: algum Ruffato de Rodeiro ou de Ubá está internado, está mal, morreu; vai casar; [...] Lamentando, Meu deus, e eu aqui nessa lonjura, trancava a porta, enfiava a chave num vão do esteio, na plataforma vigiava ansiosamente o ônibus que conduziria ao encontro dos seus. Resignado, meu pai reclamava, Qualquer espirro e chamam ela. Arruinava bonitas (só usava bonitas) atendendo a freguesia, modo de especular sobre a política municipal - um anti-Prata irremissível -, recordar tempos idos, atualizar notícias, conversar à toa. Quando principiava a toada, "Você lembra

\footnotetext{
${ }^{4}$ Terminologia que diz respeito às especificidades da voz narrativa em primeira pessoa, de acordo com os estudos de Gérard Genette (1995).
} 
do", minha mãe, impaciente, batendo com mais força a peça de roupa no esfregador, estocava, "Lá vem arrodeio" (RUFFATO, 2016, p. 13).

Nota-se o empenho da voz narrativa em reproduzir detalhes sobre a história de vida desses sujeitos. Eles são focalizados no ano de 2001, e Luiz, o narrador - que tem o nome e traços biográficos similares aos do autor ${ }^{5}$, faz questão de recriar o cenário doméstico por meio da rememoração. Contudo, esse heterocosmo se configura multifacetado, diferenciando-o de outras representações realistas: as memórias do narrador se apropriam de falas de seus familiares sem que haja separação de discursos. Essa tentativa de representação mostra-se refratária, uma vez que se percebe a valorização dos dizeres dos sujeitos que constituem a memória do narrador. Como já realizado em obras antecessoras, Ruffato, ao propor representações realistas, cria novas formas que repensam essas realidades. Especificamente em De mim já nem se lembra, a representação fragmentada da memória se articula a momentos da história através de informações presentes nas cartas. Mesmo em momentos nos quais a narração institui elementos representativos do real, nota-se que o texto não consegue ser mimético aos fatos em si: pensamento, argumentos e eventualidades são mesclados à voz do narrador.

A ideia de representação refratária se manifesta a partir da própria estruturação da narrativa. Ela está dividida em três partes. A primeira é intitulada como "explicação necessária"; a segunda, "as cartas"; e a terceira, "apêndice". Note-se que o autor se vale de um paratexto para dar cabo à narrativa, o que coloca em xeque o pacto realista em si. Nessa primeira parte, somos introduzidos ao universo da casa de Luiz, o narrador. Por meio da voz autodiegética, com focalização interna fixa, o leitor se depara com a narração in medias res:

Enxugando as mãos no avental, minha mãe veio ao meu encontro, aninhou-me em seus braços e, avesso a seu feitio, beijou-me o rosto olhos derramando saudades. Minha irmã, tomando Helena, minha filha, ao colo, sucumbia-a de afagos, Como cresceu, essa menina!, Como está linda! O chapéu puído do meu pai avivava uma conversa com o motorista do táxi, E aí, seu Moreira, muito serviço? Arrastando a mala para o cimento do terreiro, meu cunhado anunciava, Comprei aquelas duas caixas de cerveja e arrumei um pinga que, ó! Fevereiro maltratava o jardinzinho de rosas, beijos, gerânios, cravos, girassóis, azaleias, hibiscos. Suados meninos sem camisa, renunciado à bola, debruçavam sua curiosidade nos muros da casa. Vizinhas acudiam, em visitas beija-flores esfiaparam o resto da tarde (RUFFATO, 2016, p. 11).

Aqui, a instância narrativa registra, por meio de uma dicção poético-narrativa, lembranças afetivas que remetem às cenas do convívio familiar. Somos informados a respeito da vida simples de sua mãe, bem como somos apresentados à sua irmã, ao pai, aos parentes e aos amigos da família Ruffato. O narrador faz questão de criar um laço afetivo com o leitor por meio de descrições de gestos e de cenas típicas de casas do interior: "Na terça-feira à noite, o Luzimar encostou a 'chimbica', seu Chevette verde-metálico 1985 no meio-fio, aceitou o cafezinho com

\footnotetext{
${ }^{5}$ Embora se verifiquem aspectos do que a crítica contemporânea tem caracterizado como autoficção e/ou de outras estratégias performáticas nas quais há semelhanças entre autor/narrador/protagonista, nossa leitura não se atém a essa problemática.
} 
bolo de fubá que minha mãe ofertava e falou que ia levar eu e a Helena na rodoviária" (2016, p. 13). Como se constata, não há a separação entre o discurso direto ou indireto, ou mesmo a fala de uma ou outra personagem. Além disso, não se usa, com frequência, a escrita e a pontuação utilizadas na língua padrão. A nosso ver, esses experimentos corroboram com a recriação de um imaginário íntimo familiar, no qual se preservaram os sotaques, as palavras e as ações íntimas do universo doméstico, com o intuito de criar, no leitor, a sensação especial e imagética por meio dos sentidos.

Nessa primeira parte do romance, constata-se que a mãe de Luiz foi diagnosticada com câncer, o que, tempos depois, a levou a óbito. Entre lapsos de memória e narrações no presente da ação, percebe-se que a escrita é invadida pelos sentimentos de dor e inconformismo. Tendo que voltar à casa de sua mãe, ainda em 2001, no intuito de enfrentar e vasculhar os poucos pertences da matriarca, a voz narra:

\begin{abstract}
No quarto, escancarei o guarda-roupas: pendurados em cabides de arame, desolados vestidos abraçavam-se pânicos, compreendendo que aquela a quem um dia haviam servido, essa não regressaria jamais. [...] Sob a cama de casal, uma pequena e ignorada caixa retangular de madeira. Puxei-a, depositei-a na colcha-de-chenil e, ao abri-la, interromperam-se os preparativos da pachorrenta segunda-feira: ali, minha mãe abrigara seu coração esfrangalhado. Meu irmão anunciou, Tem uma firma de São Paulo, eles estão contratando todo mundo, acho que vou trabalhar lá. Muda, minha mãe estremeceu... Meu pai comentou, Se for pro seu bem... Minha irmã e eu escutamos, apenas. Tornou, em definitivo, sete anos depois, dentro de um caixão que nem pôde ser descerrado, tão desfigurado o corpo. Um desastre, entre Vassouras e Paraíba do Sul: do carro que estreava restaram ferragens contorcidas (RUFFATO, 2016, p. 20-21, grifos no original).
\end{abstract}

Nesse quarto, o narrador se depara com um retrato do irmão - pintado, como era de costume de famílias antigas - exposto em moldura oval; a morsa feita pelo irmão - resultado de seu trabalho de conclusão de curso de torneiro-mecânico no Senai de Cataguases - e um maço de cartas, que o narrador portou consigo e levou embora. Anos depois, ao mudar de endereço e de apartamento, Luiz resolve, então, examinar as cartas:

Em fins de 2003, empacotava objetos para mais uma mudança de endereço - a vigésima sexta em minha vida -, quando, ao retirar livros de uma prateleira na estante, me deparei com o maço de cartas. Imediatamente, sentei-me no chão empoeirado do apartamento vazio e desatei o barbante. Cuidadosamente enfileiradas por data, cinquenta cartas sobrescritadas por meu irmão à minha mãe. Perturbado, percorri, uma a uma, as páginas compostas em letra miúda e desenhada, relatando ninharias, reclamando novidades. Aqui reúno esse passado - modo de reparar meus mortos, que já pesam no lado esquerdo: meu irmão, minha mãe, meu pai, aqueles aos quais me reunirei um dia. A eles, este livro (RUFFATO, 2016, p. 22).

Após essa narração - que também pode ser lida como uma espécie de "dedicatória" e/ou, também, como um prefácio/advertência aos leitores a respeito da leitura das epístolas - a voz narrativa cede lugar à grafia do "espectro" por meio de seus "arquivos": convoca-se a voz silenciada de seu irmão por meio da reapropriação das cartas. A esse respeito, há a nota de rodapé 
que antecede ao trabalho de edição das missivas: "as cartas reproduzo-as integralmente, apenas atualizando e corrigindo a ortografia e muito raramente a pontuação - procurei manter sua quase-oralidade" (2016, p. 22).

\section{Edição das cartas: o Realismo refratário na escrita epistolar de José Célio}

De acordo com Carlos Reis (1988, p. 30), o narrador, ao assumir a função de editor de cartas, não é impedido de lançar sua suspeição de ficcionalidade sobre as elas. Essa estratégia propositalmente utilizada por Ruffato joga com os limites entre realidade e ficção. Tal evidência pode nos levar a aceitar as cartas como constructos ficcionais, uma vez que fazem parte do universo diegético. Entretanto, o estudo dessa escrita de si pressupõe a percepção de muitas camadas de significado, leituras de texto e do contexto. Logo, a voz resgatada do personagem-missivista, José Célio, pode ser vista, também, como um meio privilegiado de transmissão de informação que ilumina visões de sujeitos, até então, nulos na história. O narrador, por sua vez, ao assumir

[...] uma função mediadora que não tem documentos muitas vezes apresentados como autênticos, mas também, não raro (sobretudo quando é mais acentuada a tarefa organizativa, seletiva ou corretiva da função editorial), a salvaguarda da narratividade, por cumprir ao editor configurar ou reforçar a dinâmica narrativa decorrente da articulação das diversas peças editadas (REIS e LOPES, 1988, p. 32).

O personagem José Célio, como informado pelo narrador, assume a voz na narrativa. Ele deixa a cidade de Cataguases e se muda para São Paulo, em 1971, em busca de emprego. Célio representa, como também destacou Fritzen (2015), o processo migratório interno no Brasil naquela época. Muitos jovens migraram para os grandes centros, principalmente para a região do ABC paulista. Na tentativa de amenizar a dor e a saudade da família, Célio criou um fluxo de escrita de cartas, todas endereçadas à mãe, que vão de 1971 a 1978.

Diferentemente de romances epistolares clássicos - tais como As relações perigosas (1782), de Chordelos de Laclos, em que há a troca de cartas entre o grupo de indivíduos - a revitalização dessa escrita epistolar dentro do romance não se materializa por meio de trocas de correspondência: há, apenas, a escrita do remente das cartas, cuja produção se estende por 7 anos ininterruptos. Ruffato, ao eliminar do romance a outra face do trânsito epistolar - o destinatário das cartas que, no caso específico, seria a mãe de Célio, uma vez que não há nenhuma correspondência de autoria da progenitora - torna o leitor o receptor dessas missivas. Ao assumir essa função dentro da narrativa, o leitor torna-se responsável por examinar as informações presentes nas cartas, de temporalidades distintas, e por detectar indícios de tortura, de desaparecimentos e até mesmo possíveis mortes de indivíduos do convívio de Célio.

Na primeira carta, escrita em São Paulo e datada 2 de fevereiro de 1971, o filho informa à mãe sobre os pormenores de sua viagem e sobre o grande período que passou no ônibus. Além de assuntos triviais, verifica-se a visão de mundo de um sujeito comum, simples e que não tem dimensão do que está acontecendo no país. Contudo, ele sempre se mostra ressabiado e detalha: 
“[...] E o pai, melhorou a tosse? Fala com ele que eu não esqueci dos conselhos dele não: só falo com as pessoas que o Nilson me diz que é colega dele ou conhecido" (RUFFATO, 2016, p. 27). Nessa e na grande maioria das cartas, Célio descreve eventos corriqueiros do dia a dia, bem como relata saudades de casa. Destaca como é o quarto da pensão no qual se instalou, conta sobre as amizades que fez bem e suas tentativas de namoro que não vingaram. Entretanto, a partir da carta datada de 13 de janeiro de 1974, Célio relata à mãe a respeito de coisas estranhas que estão acontecendo com seus companheiros de fábrica na cidade de Diadema, onde se instalou para trabalhar na metalurgia:

\section{Diadema, 22 de junho de 1974}

[...] Outro dia, aconteceu um negócio esquisito com um rapaz que mora comigo na pensão, o Norivaldo, um sujeitinho falante, desses meio entrão, sabe? Parece que ele estava andando na rua, o pessoal da cavalaria que tem aqui perto passou, ele fez pouco dos soldados, um deles desceu, mandou ele beijar o cavalo, ele falou que não ia beijar coisa nenhuma, eles carregaram ele para a delegacia e deram uma surra danada nele. Parece que o negócio foi feio, porque ele apareceu na pensão todo machucado, eu não vi não, me contaram, pegou a bolsa dele e sumiu. Ninguém mais ouviu falar dele. A gente tem que tomar cuidado com quem fala por aqui. Eu tomo (RUFFATO, 2016, p. 82).

Embora não compreenda o que de fato está acontecendo ao seu redor, Célio fica preocupado. Seus escritos revelam indícios de maus tratos e de tortura com os trabalhadores das fábricas. Interessante notar, também, que nessa carta, o narrador faz um comentário perspicaz em forma de nota de rodapé: "Embora não datada, esta carta provavelmente foi escrita no dia 18 de agosto de 1974, há que o carimbo postal é do dia 19 de agosto de 1974" (2016, p. 83). Na função de editor, o narrador induz o leitor à constatação de que Norivaldo, o colega de trabalho de Célio, ou havia sido torturado ou morto:

[...] Lembra daquele rapaz, o Norivaldo, que falei para a senhora? Pois ele não apareceu nunca mais. E ainda deixou umas contas penduradas com a dona Sinoca, coitada. O Fabinho, que é uma pessoa bem informada, falou que o problema é a ditadura, que eles prendem e desaparecem com a pessoa. Também, tem um pessoal que gosta de uma folia. Eu fico quieto no meu canto. Não me meto com ninguém (RUFFATO, 2016, p. 84).

Para Haroche-Bouzinac, a carta é um "gênero de fronteira", "essencialmente híbrido", "maleável" e resiste a conceituações estritas. Por se tensionar entre a norma e a inventividade, o privado e o público, ela pode servir como um elemento importante na representação de realidades refratárias. A carta, mesmo que fictícia tal como é utilizada por Ruffato, pode ser lida como “[...] testemunho do indivíduo que escreve, testemunho do grupo social ao qual pertence ou tenta se integrar, bem como representação contínua de uma ordem social" (HAROCHE-BOUZINAC, 2016, p. 25). Não à toa, essa escrita de si se encontra na encruzilhada dos caminhos individuais e coletivos, muito embora não possamos perder de vista que "a carta [...] é sempre, e em diversos graus, uma encenação de si. A sinceridade do epistológrafo não passa de um mito no qual alguns tem acreditado" (2016, p. 24). Outra missava que pode ser lida sob o viés do testemunho, ou seja, 
de um sujeito anônimo que vivenciou sob outros ângulos o contexto repressor, foi escrita em 1976, no auge dos anos de chumbo. Nela, Célio escreve:

Diadema, 5 de dezembro de 1976

Mãe,

Vou conseguir passar o fim de ano aí sim. Estava meio difícil, porque estou meio sem dinheiro, mas pode me esperar que eu vou. Desta vez não vou levar presentes não, mas faço questão da gente comer peru no Natal. Vê aí onde tem, compra, e eu reponho o dinheiro. Devo mudar de pensão no começo do ano. Tem um rapaz que mudou para aqui que o pessoal do sindicato me falou que não é para confiar nele não, que ele é dedo-duro da Polícia Federal. Que ele está em Diadema para vigiar a gente e entregar para o governo, porque a senhora sabe que a gente vive debaixo de uma ditadura que prende e mata trabalhadores, que a única coisa que querem é mudar a situação injusta do país, mas a senhora nem fale isso aí em Cataguases não, senão eles ainda prendem a senhora e dizem que a senhora é comunista. Mãe era bom até a senhora rasgar essas cartas, porque vai que alguém pega e lê e ainda pode dar probleminha. Devo estar chegando aí no dia 22 de manhã, se Deus quiser. Seu filho, Célio (RUFFATO, 2016, p. 114-115).

O missivista, embora ainda não tenha dimensão do que seja a ditatura e nem dos perigos que o cercam, continua, incessantemente, a escrever. Ao compartilhar com os leitores assuntos de foro íntimo - tais como são pensadas primordialmente as cartas -, cujos conteúdos são reservados aos seus destinatários, os leitores da narrativa de Ruffato passam a compartilhar uma nova possibilidade de repensar a ditadura: quais sujeitos e como eles vivenciaram tais horrores? Que aprendizados tiramos dessas missivas? Lidas como "vestígios de histórias em migalhas", as "correspondências familiares fazem reviver histórias singulares na história". (HAROCHE-BOUZINAC, 2016, p. 24).

Em outra epístola, Célio evidencia um acontecimento importante relacionado às greves e às reinvindicações dos trabalhadores do grande $\mathrm{ABC}$, que repercutiram nacionalmente. Segundo o historiador Marcos Napolitano (2019, p. 277), “em setembro de 1977, [...] os metalúrgicos de São Bernardo lançaram a 'campanha de reposição dos 34\%', índice de perdas calculado devido à manipulação das taxas de inflação em 1973". Esse "novo sindicalismo" - no qual surgia Lula, importante líder sindical - marcou a volta das assembleias operárias massivas. Célio, em carta redigida em 9 de outubro de 1977, descreve esse fato histórico dando ênfase às conquistas dos metalúrgicos:

Diadema, 9 de outubro de 1977

Mãe,

Setembro foi um mês complicado para nós. Ninguém falou nada, mas conseguimos mobilizar um mundaréu de gente na nossa campanha pela reposição dos 34,1\%, quer dizer, para repor no nosso salário um índice que o governo roubou do trabalhador. O pessoal do sindicato ficou contente para burro, porque os mais velhos falaram que desde o começo da ditadura não viam coisa assim acontecer por aqui. Agora, vamos preparar para o ano que vem. Está todo mundo animado e já tem gente falando que agora a coisa vai. 
[...] Por aqui, está tudo bem. Estou muito bem instalado na casa de dona Neilane. Os filhos dela são muito legais. Eles são metalúrgicos também (RUFFATO, 2016, p. 123).

Por meio dessas missivas, mesmo que construídas ficcionalmente a serviço da narrativa realista, os leitores podem desenvolver outras percepções sobre o que poderiam ter sido os anos de chumbo. Normalmente, temos acesso aos traumas da ditadura por meio de relatos em biografias ou de estudos de historiadores. Ficcionalizando os relatos de sujeitos silenciados, percebemos que "o passado está aberto para novas interpretações, donde a importância da literatura para reelaborar os traumas causados pela ditadura" (FIGUEIREDO, 2017, p. 41).

A última carta de Célio é datada de 5 de março de 1978. Escrita em Diadema, como quase todas as anteriores, o epistológrafo relata que irá estrear o seu carro novo - comprado com suas economias de seis anos - no caminho até a cidade de Leopoldina, em Minas Gerais, juntamente com um colega que mora em Mutum, cidadezinha mineira. Após deixar o colega em Leopoldina, Célio iria sozinho até Cataguases. Contudo, tal feito não se concretizou. Em nota de rodapé, o editor das cartas - o narrador Luiz - relata que esse colega desistiu de ir com Célio nessa viagem e, então, notifica o leitor sobre a tragédia que acometeu seu irmão: [...] "A polícia rodoviária nos informou que ele provavelmente dormiu no volante, atravessando a estrada e metendo-se sob um caminhão. O que importa é que nos deixou uma semana após completar vinte e seis anos, aberta uma chaga nunca mais cicatrizada" (RUFFATO, 2016, p. 128).

Por fim, na última parte da diegese - intitulada "apêndice" - Luiz reassume a voz narrativa e escreve, 30 anos depois da morte de Célio, uma carta dedicada ao irmão. Datada de 15 de março de 2008 e em um tom comovente e saudosista, Luiz relata: “[...] envelheci, envelhecemos todos... Menos você, que permanece com 26 anos, ardendo inexoravelmente em minhas lembranças" (2016, p. 136). Com esse final inesperado, Ruffato nos oferece, por meio de tentativas refratárias de representar o real, uma realidade que só seria possível no universo romanesco.

\section{REFERÊNCIAS}

BARTHES, Roland. O efeito do real. In: O rumor da língua. Tradução por Mário Laranjeira. São Paulo: Martins Fontes, 2004. p. 181-190.

BURKE, Peter (Org.). Abertura: a nova história, seu passado e seu futuro. In: A escrita da história: novas perspectivas. Tradução por Madga Lopes. São Paulo: Editora Unesp, 2011. p. 7-38.

CARRIZO, Silvina; CERQUEIRA, Rodrigo. Abandono e sobrevivência: o sujeito migrante na obra de Luiz Ruffato. Ipotesi, v.16, n.1, p. 55-63, jan./jun. 2012.

FIGUEIREDO, Eurídice. A literatura como arquivo da ditadura brasileira. Rio de Janeiro: 7 Letras, 2017.

FRITZEN, Gecielli. Uma leitura dos modos de vida e do trabalho fabril no romance De mim já nem se lembra, de Luiz Ruffato. Dissertação (Mestrado em Literatura). Universidade Federal de Santa Catarina, Florianópolis, 2015.

GAGNEBIN, Jeanne Marie. Lembrar escrever esquecer. Tradução por Guido Antônio de Almeida. São Paulo: Editora 34, 2006. 
GENETTE, Gérard. Discurso da narrativa. Tradução por Fernando Cabral Martins. Lisboa: Vega, 1995.

HABERT, Nadine. A década de 70: apogeu e crise da ditadura militar brasileira. São Paulo: Ática, 2006.

HAROCHE-BOUZINAC, Geneviève. Escritas epistolares. Tradução por Ligia Fonseca Ferreira. São Paulo: Editora da Universidade de São Paulo, 2016.

LACLOS, Chordelos de. As relações perigosas ou cartas recolhidas num meio social e publicadas para ensinamento de outros. Tradução por Carlos Drummond de Andrade. São Paulo: Globo, 2013.

NAPOLITANO, Marcos. 1964: história do regime militar brasileiro. São Paulo: Contexto, 2019.

NORA, Pierre. Les lieux de mémoire. Paris: Gallimard, 1985.

PELLEGRINI, Tânia. Realismo: a persistência de um mundo hostil. Revista Brasileira de Literatura Comparada, v. 1, n. 14, p. 11-36, 2009.

PELLEGRINI, Tânia. Realismo e realidade na literatura: um modo de ver o Brasil. São Paulo: Alameda, 2018.

POLLAK, Michael. Memória, Esquecimento, Silêncio. Estudos históricos, v. 2, n. 3, p. 3-15, 1989.

RANCIĖRE, Jacques. A partilha do sensível: estética e política. Tradução por Mônica Costa Netto. São Paulo: Editora 34, 2009.

REIS, Carlos; LOPES, Ana. Dicionário de teoria da narrativa. São Paulo: Ática, 1988.

ROBERT, Marthe. Romance de origens, origens do romance. Tradução por André Telles. São Paulo: Cosac \& Naify, 2007.

RUFFATO, Luiz. De mim já nem se lembra. São Paulo: Companhia das Letras, 2016.

SCHØLLHAMMER, Karl. Ficção brasileira contemporânea. Rio de Janeiro: Civilização brasileira, 2009.

SHARPE, Jim. A história vista de baixo. In: BURKE, Peter (Org.). A escrita da história: novas perspectivas. Tradução por Magda Lopes. São Paulo: Editora Unesp, 2011. p. 39-63.

WATT, Ian. A ascensão do romance. Tradução por Hidelgard Feist. São Paulo: Companhia das Letras, 1990. 